\title{
Nilai dan Pola Transit Oriented Development(TOD) Indeks pada Jalur Commuter Line Bogor - Jakarta Kota
}

\author{
The Value and Pattern of Transit Oriented Development (TOD) Index on Bogor - \\ Jakarta Kota Commuter Line Lane
}

\section{Dewanti Aisyah Legowo 1}

Universitas Indonesia, Depok, Indonesia

\section{Widyawati Sumadio 2}

Universitas Indonesia, Depok, Indonesia

Artikel Masuk : 20 November 2020

Artikel Diterima : 21 Juni 2021

Tersedia Online : 31 Agustus 2021

\begin{abstract}
Abstrak: Dalam upaya menuju kota berkelanjutan, Jakarta terus meningkatkan berbagai fasilitas publiknya, antara lain dengan menerapkan konsep Transit Oriented Development (TOD). Penelitian ini bertujuan untuk mengetahui dan menganalisis nilai dan pola suatu TOD pada jalur commuter line Bogor - Jakarta Kota. Penelitian dilakukan pada tujuh jalur KA komuter TOD antara Stasiun Bogor dan Jakarta Kota. Pengumpulan data dilakukan dengan mengumpulkan informasi dari berbagai sumber dan mengamati stasiun-stasiun kereta api dengan mengunjungi langsung stasiun-stasiun tersebut. Selanjutnya hasil analisis data dikategorikan menurut variabel dan kriteria yang ditentukan dalam TOD indeks. Analisis deskriptif digunakan untuk membagi tipologi TOD menjadi TOD kota dan TOD lingkungan. Hasil penelitian menunjukkan bahwa nilai indeks TOD tertinggi terdapat pada TOD Stasiun Jakarta Kota yang merupakan TOD Kota dan nilai terendah terdapat pada TOD Stasiun Tanjung Barat yang merupakan TOD lingkungan. Bentuk indeks TOD bervariasi. Stasiun kereta api Depok yang terletak di bagian selatan dan stasiun kereta api Jakarta Kota yang terletak di bagian utara jalur memiliki indeks yang tinggi. Sedangkan stasiun kereta api yang berada di antara kedua stasiun ini memiliki indeks yang rendah. Variabel yang paling berpengaruh adalah variabel internal yang ditunjukkan oleh fasilitas stasiun. Area kantor dan akses bolak-balik ke stasiun merupakan kriteria yang paling penting di antara variabel eksternal lainnya. Kesimpulan dari penelitian ini menunjukkan bahwa nilai indeks yang tinggi tidak selalu sesuai dengan status TOD, baik sebagai TOD lingkungan maupun sebagai TOD kota. Pada TOD dengan indeks yang tinggi, kedua variabel tersebut tidak selalu memberikan peran yang sama..
\end{abstract}

Kata Kunci: pembangunan perkotaan; transit oriented development (TOD); transportasi; TOD indeks

\footnotetext{
${ }^{1}$ Korespondensi Penulis: Universitas Indonesia, Depok, Indonesia Email: Dewa.aisyah@gmail.com

2 Korespondensi Penulis: Universitas Indonesia, Depok, Indonesia Email: widyawatihs@gmail.com
} 


\title{
143 Nilai dan Pola Transit Oriented Development (TOD) Indeks...
}

\begin{abstract}
Designated as a sustainable city, Jakarta continues to improve its various public facilities, among others, by applying the TOD concept. This study aims to analyse the value and pattern of the TOD index on the Bogor-Jakarta Kota Commuter Line lane. The study was conducted on seven TOD commuter line between Bogor and Jakarta Kota railway stations. Data collecting was done by downloading information from various sources and observe the railway stations by visiting directly to the stations. Furthermore, the results of the data are categorized according to variables and criteria specified in the TOD Index. Descriptive analysis is used to divide TOD typology into city TOD and neighbourhood TOD. The results show that the highest TOD index value is found at Jakarta Kota Station which is the City TOD and the lowest value is at Tanjung Barat Station TOD which is the neighbourhood TOD. The form of the TOD index varies. Depok railway station that lies in the southern part and Jakarta Kota railway station situated in the northern part of the lane have high indexes. While railway stations that lie between these two stations have low indexes. The most influential variable is the internal variable, which shows by the station facilities. Office area and access back and forth to the stations are criteria that are the most important among other external variables. The conclusion of this study shows that a high index value does not always correspond to the TOD status, either as neighbourhood TOD or as city TOD. In TOD with a high index, the two variables do not always give the same role.
\end{abstract}

Keywords: transit oriented development (TOD); transportation; TOD index; urban development

\section{Pendahuluan}

Kota Jakarta sebagai kota terbesar di Indonesia, selain merupakan pusat pemerintahan juga menjadi pusat kegiatan ekonomi yang melayani seluruh Indonesia. Berdasarkan data Badan Pengelola Transportasi Jabodetabek (2018), setidaknya ada 49,5 juta perjalanan orang per hari. Perjalanan tersebut terbagi menjadi dua, yaitu pergerakan di dalam kota sebanyak 23,4 juta, sedangkan 20,02 juta lainnya merupakan warga Bogor, Depok, Tangerang, dan Bekasi (Bodetabek) yang melakukan mobilitas dari luar kota menuju dalam kota Jakarta. Saat ini Jakarta telah memiliki beragam pilihan transportasi umum untuk memfasilitasi pergerakan penduduk, di antaranya kereta Commuter Line, Bus Trans Jakarta, Ojek Online, Moda Raya Terpadu (MRT), dan Lintas Rel Terpadu (LRT) dan terus berbenah agar mampu memiliki transportasi umum yang baik (Sari, 2019). Salah satu bentuk kelengkapan dan kelayakan sebuah transportasi umum dapat dilihat melalui ketersediaan fasilitas keterjangkauan, efisiensi, kenyamanan, dan keberlanjutan (Knupfer et al., 2018). Keberlanjutan dalam sebuah kota sangatlah penting karena kota merupakan tempat utama bagi masyarakat perkotaan melakukan aktivitasnya sehari-hari. Pembangunan mengenai kota berkelanjutan itu sendiri juga sudah tercantum dalam Sustainable Development Goals (SDGs) ke 11. Keberlanjutan yang sukses pada sebuah kota menurut Institute of Transportation and Development Policy (ITDP), (2017), akan memprioritaskan manusia dengan cara mengintegrasikan sistem transportasi dengan pengembangan/pembangunan kota, salah satunya dengan menerapkan konsep Transit Oriented Development (TOD).

TOD merupakan salah satu konsep dalam pengembangan tata kota yang memiliki karakteristik mudah diakses, adanya pengembangan bangunan multifungsi yang berdekatan dengan fasilitas transit dan menyediakan tempat bagi pejalan kaki (Cervero et al., 2004). Penerapan konsep TOD diharapkan dapat mengurangi kepemilikan dan penggunaan kendaraan pribadi. Hal ini akan meningkatkan efisiensi dalam berkendara dan beraktivitas dengan kendaraan umum, terutama pada kawasan dalam radius 0 hingga 800 meter dari titik pusat transit (Rahmat et al., 2016). Penelitian Arif \& Manullang (2017) melakukan analisis akses TOD dengan menggunakan jarak 600 meter sebagai jalur berjalan 
kaki. Oleh karena itu, kualitas suatu sistem transit menjadi penting dalam TOD (Newman 2009).

Sebuah TOD yang berhasil berpengaruh pada berkurangnya kemacetan dan meningkatnya kualitas udara (Cervero et al., 2004). Hal ini akan menciptakan kota yang menyenangkan, dikarenakan memiliki lingkungan yang lebih layak untuk ditinggali, tempat jalur pejalan kaki dan jalur sepeda yang lebih ramah. Selanjutnya, kota akan mengalami pertumbuhan kehidupan yang berkualitas dan menjadi kota yang berkelanjutan (Hasibuan et al., 2014).

Penelitian TOD khususnya di Jabodetabek telah banyak dibahas dan saat ini pemerintah juga telah menetapkan beberapa lokasi TOD. Lokasi-lokasi TOD tersebut ada yang terdapat pada jalur commuter line. Commuter Line merupakan salah satu moda transportasi publik yang menjadi pilihan terbaik transportasi perkotaan. Jalur commuter line Bogor-Jakarta Kota memiliki jumlah pengguna terbanyak perharinya, yaitu mencapai 546.420 pengguna atau 69\% dari keseluruhan pengguna. Oleh karena itu, stasiun-stasiun yang terdapat pada jalur tersebut sangat berpotensi untuk menjadi sebuah TOD. Berdasarkan Mungkasa (2018) dan Pemerintah Republik Indonesia (2018), terdapat tujuh lokasi stasiun yang ditetapkan sebagai sebuah TOD yaitu stasiun Depok Baru, Pondok Cina, Tanjung Barat, Cawang, Manggarai, Juanda, dan Jakarta Kota. Pada kenyataannya beberapa TOD di Jabodetabek masih belum maksimal karena belum sepenuhnya mengintegrasikan transportasi umum, dan belum sepenuhnya memenuhi indikatorindikator yang ada. Oleh karena itu, penelitian ini bertujuan untuk mengetahui dan menganalisis nilai dan pola suatu TOD pada jalur commuter line Bogor - Jakarta Kota.

\section{Metode Penelitian}

TOD indeks digunakan untuk mengukur TOD suatu tempat (Evans \& Pratt, 2007). Pada penelitian ini TOD Indeks diukur dengan menggunakan kriteria kepadatan, keragaman penggunaan lahan, akses dengan jalan kaki, area perkantoran, kapasitas stasiun, fasilitas stasiun, aksesibilitas dari dan ke stasiun, dan ketersediaan lahan parkir (Singh et al., 2017). Sehingga dapat diketahui nilai sebuah TOD dan variabel apa yang paling mempengaruhi dan apa yang harus ditingkatkan.

Penelitian dilakukan di wilayah cakupan commuter line jalur Bogor - Jakarta Kota. Fokus dalam penelitian terdapat pada tujuh stasiun yaitu Stasiun Depok Baru, Pondok Cina, Tanjung Barat, Cawang, Manggarai, Juanda, dan Jakarta Kota. Tujuh stasiun tersebut dianggap paling tepat untuk dipilih karena tercantum pada berbagai sumber seperti: Peraturan Presiden Nomor 55 tahun 2018 tentang Rencana Induk Transportasi Jabodetabek tahun 2018 - 2029, Presentasi Deputi Gubernur DKI Jakarta tahun 2018, Dinas Perhubungan dan Pemerintah Kota Depok pada 2020, Kementerian Perhubungan, dan Badan Perencanaan dan Pembangunan Nasional.

Pada penelitian ini, area analisis dibatasi sejauh 500 meter dari stasiun. Jarak 500 meter tersebut dipilih berdasarkan jarak berjalan kaki yang nyaman bagi masyarakat Indonesia (Nusdwinuringtyas, 2018) dan merujuk kepada Peraturan Presiden Nomor 55 tahun 2018 tentang Rencana Induk Transportasi Jakarta, Bogor, Depok, Tangerang dan Bekasi Tahun 2018 - 2029 pada butir 5 \& 7, disebutkan bahwa "akses jalan kaki ke angkutan umum maksimal $500 \mathrm{~m}$ (lima ratus meter), dan simpul transportasi perkotaan harus memiliki fasilitas pejalan kaki dan fasilitas parkir pindah moda (park and ride), dengan jarak perpindahan antar moda tidak lebih dari $500 \mathrm{~m}$ (lima ratus meter)".

Dalam pengolahan data, standarisasi metode Min- Max digunakan. Hal ini dilakukan untuk menghitung perbedaan unit pada seluruh indikator. Perhitungan standarisasi atau normalisasi bertujuan menstandarisasi nilai yang bersifat tabulasi guna berada pada rentang nilai 0-1 dalam perhitungan TOD Indeks, yang dijelaskan dengan persamaan (1). 


$$
y=\frac{(x-\min (d)) \times(\max (n)-\min (n))}{\max (d)-\min (d)}+\min (n)
$$

Keterangan: $\max (\mathrm{d})=$ nilai tertinggi atau maksimum pada data; $\min (\mathrm{d})=$ nilai terendah atau minimum pada data; $\max (\mathrm{n})=$ nilai maksimum pada rentang yang ditentukan, dalam penelitian ini nilai maksimum adalah 1 ; dan $\min (\mathrm{n})=$ nilai minimum pada rentang yang ditentukan, dalam penelitian ini nilai minimum adalah 0 .

Persamaan (1) ini kemudian digunakan untuk pengukuran tahap selanjutnya, yaitu pengukuran yang didasarkan pada pembobotan. Kriteria indikator dan bobot yang digunakan dalam penelitian ini mengacu pada penelitian yang dilakukan oleh Singh (2015) dan beberapa indikator dimodifikasi sesuai dengan kondisi lapangan, namun bobot maksimal yang diberikan tetap berada pada angka satu (Siburian et al., 2020). Pemberian bobot dengan nilai tinggi berdasarkan pentingnya variabel tersebut pada sebuah TOD, namun kedudukannya akan sama pada seluruh stasiun.

Pembobotan dilakukan dengan cara mengalikan nilai dengan bobot. Apabila dalam satu kriteria terdapat beberapa indikator, maka indikator-indikator tersebut kemudian dijumlahkan. Setelah didapatkan hasil untuk masing-masing kriteria maka dilakukan pembobotan kembali dan akan didapatkan hasil nilai sebuah TOD Indeks (Tabel 1).

Tabel 1. Kriteria, Bobot, dan Indikator yang Digunakan dalam Penelitian Ini

\begin{tabular}{|c|c|c|c|}
\hline Kriteria & Bobot & Indikator & Bobot \\
\hline \multirow[t]{3}{*}{ Kepadatan } & 0,15 & Kepadatan populasi & 0,67 \\
\hline & & Kepadatan Komersial (toko/ruko) & 0,11 \\
\hline & & Kepadatan Komersial (mall/plaza) & 0,22 \\
\hline Keragaman penggunaan lahan & 0,03 & Keragaman penggunaan lahan & 1 \\
\hline \multirow[t]{4}{*}{ Aksesibilitas } & 0,06 & Keragaman Permukiman & 0,1 \\
\hline & & Jaringan Jalan & 0,4 \\
\hline & & Kerapatan persimpangan & 0,2 \\
\hline & & Luas jangkauan pejalan kaki & 0,3 \\
\hline \multirow[t]{3}{*}{ Area perkantoran } & 0,22 & Kerapatan bangunan ruko kantor (Rukan) & 0,2 \\
\hline & & Kerapatan bangunan kantor pemerintah & 0,3 \\
\hline & & Kerapatan bangunan kantor besar & 0,5 \\
\hline Kapasitas stasiun & 0,19 & Jumlah Pengunjung Stasiun & 1 \\
\hline \multirow{2}{*}{ Fasilitas stasiun } & 0,11 & Keselamatan dan Keamanan & 0,5 \\
\hline & & Tampilan informasi & 0,5 \\
\hline \multirow[t]{5}{*}{ Akses dari dan ke stasiun } & 0,15 & Frekuensi Perjalanan Commuter Line & 0,4 \\
\hline & & Percabangan jalur di Stasiun & 0,3 \\
\hline & & Ketersediaan angkutan alternatif (angkot \& bus) & 0,067 \\
\hline & & Ketersediaan angkutan alternatif (BRT) & 0,133 \\
\hline & & $\begin{array}{l}\text { Lokasi bangunan yang dapat dicapai dengan } \\
\text { berjalan kaki }\end{array}$ & 0,1 \\
\hline \multirow[t]{2}{*}{ Ketersediaan lahan parkir } & 0,08 & Ketersediaan parkir mobil & 0,67 \\
\hline & & Ketersediaan parkir motor & 0,33 \\
\hline
\end{tabular}

Metode pengumpulan data yang dilakukan dalam penelitian ini dijelaskan dalam Tabel 2 dan selanjutnya nilai sebuah TOD indeks dari ketujuh stasiun dilihat dan dianalisis untuk menentukan TOD dengan indeks tertinggi dan terendah. Kemudian dilakukan perbandingan manakah variabel yang paling dominan membentuk nilai sebuah TOD. 
Tabel 2. Metode Pengumpulan Data

\begin{tabular}{|c|c|c|}
\hline Kriteria & Indikator & Sumber Data \\
\hline Kepadatan & $\begin{array}{l}\text { Kepadatan populasi } \\
\text { Kepadatan Komersial (toko/ruko) } \\
\text { Kepadatan Komersial (mall/plaza) }\end{array}$ & $\begin{array}{l}\text { Open street map 2020, Digitasi Google } \\
\text { earth, dan observasi lapang }\end{array}$ \\
\hline $\begin{array}{l}\text { Keragaman } \\
\text { penggunaan lahan }\end{array}$ & Keragaman penggunaan lahan & \\
\hline Aksesibilitas & $\begin{array}{l}\text { Keragaman Permukiman } \\
\text { Jaringan Jalan } \\
\text { Kerapatan persimpangan } \\
\text { Luas jangkauan pejalan kaki }\end{array}$ & \\
\hline Area Perkantoran & $\begin{array}{l}\text { Kerapatan bangunan ruko kantor } \\
\text { (rukan) } \\
\text { Kerapatan bangunan kantor } \\
\text { pemerintah } \\
\text { Kerapatan bangunan kantor besar }\end{array}$ & \\
\hline Kapasitas stasiun & Jumlah Pengunjung tiap stasiun & Proyeksi dari data tahun 2013 \\
\hline Fasilitas Stasiun & $\begin{array}{l}\text { Keselamatan dan Keamanan } \\
\text { Tampilan informasi }\end{array}$ & Observasi lapang \\
\hline Aksesibilitas & $\begin{array}{l}\text { Frekuensi perjalanan Commuter Line } \\
\text { Percabangan jalur di Stasiun } \\
\text { Ketersediaan angkutan alternatif } \\
\text { (angkot \& bus) } \\
\text { Ketersediaan angkutan alternatif } \\
\text { (BRT) }\end{array}$ & $\begin{array}{l}\text { PT.KCI } \\
\text { Peta Commuter Line } \\
\text { Trovit, moovit }\end{array}$ \\
\hline & $\begin{array}{l}\text { Lokasi yang bangunan yang dapat } \\
\text { dicapai dengan berjalan kaki }\end{array}$ & $\begin{array}{l}\text { Open street map 2020, Digitasi Google } \\
\text { earth, dan observasi lapang }\end{array}$ \\
\hline $\begin{array}{l}\text { Ketersediaan lahan } \\
\text { parkir }\end{array}$ & $\begin{array}{l}\text { Ketersediaan parkir mobil } \\
\text { Ketersediaan parkir motor }\end{array}$ & Observasi lapang \\
\hline
\end{tabular}

\section{Kepadatan}

Kriteria kepadatan meliputi kepadatan populasi dan kepadatan bangunan komersial pada luasan tertentu (wilayah buffer 500 meter). Total populasi didapatkan melalui perhitungan dengan mengalikan jumlah bangunan permukiman (rumah perorangan dan unit yang terdapat dalam rumah komunal) dengan empat jiwa. Kepadatan komersial dinilai dengan unit bangunan komersial, dan dalam penelitian ini terbagi menjadi dua bagian yaitu toko atau ruko dan mall atau plaza.

\section{Keragaman Penggunaan Lahan}

Konsep keragaman penggunaan lahan pada kawasan TOD berasal dari penelitian Kamruzzaman et al. (2014) yang dihitung menggunakan persamaan (2).

$$
\left(\text { Penggunaan Lahan }=1-\sum\left(\frac{\alpha}{A}\right)^{2}\right)
$$

$\alpha$ adalah total area dari kategori penggunaan lahan tertentu dalam buffer TOD, dan A adalah total area dari semua kategori penggunaan lahan dalam buffer TOD. Penggunaan lahan yang dihitung luasannya meliputi lahan residensial dan komersial. Nilai kedua penggunaan lahan ini dijumlahkan guna mendapatkan nilai keragaman penggunaan lahan pada setiap stasiun TOD commuter line Bogor - Jakarta Kota. 


\section{Aksesibilitas}

Indikator yang dihitung pada kriteria aksesibilitas meliputi keragaman permukiman, jaringan jalan, persimpangan dan jangkauan pejalan kaki.

\section{Keragaman Permukiman}

Keragaman permukiman dalam penelitian ini mengikuti rumus (Zhang \& Guindon, 2006), yang ditampilkan pada persamaan (3).

$$
\mathrm{MI}(\mathrm{i})=1+\frac{\sum_{\mathrm{n} i} S_{c}}{\sum_{\mathrm{n} i}\left(S_{c}+S_{r}\right)}
$$

Keterangan: $\mathrm{MI}(i)=$ Keragaman untuk bidang analisis pemukiman; $\mathrm{Sc}=$ jumlah total area dalam penggunaan lahan kota non-perumahan; dan $\mathrm{Sr}=$ jumlah total area dalam penggunaan lahan perumahan dalam i.

Nilai MI dapat berkisar dari 0 hingga 1 , penggunaan lahan dengan nilai 0,5 menyiratkan total area yang sama dari penggunaan lahan lainnya. Indikator ini berbeda dari keragaman penggunaan lahan (Jacobs, 1961), (Evans \& Pratt, 2007), (Zhang \& Guindon, 2006), dan (Ewing et al., 2006).

\section{Jaringan Jalan}

Indikator jaringan jalan dihitung berdasarkan jalan yang dapat diakses oleh para pejalan kaki maupun pengendara sepeda dalam area analisis pada setiap stasiun. Tipe jaringan jalan berupa jalan tol dihapuskan karena berjalan kaki maupun bersepeda tidak diizinkan pada tipe jalan tersebut.

\section{Persimpangan}

Kepadatan persimpangan diukur dengan jumlah banyaknya persimpangan pada wilayah analisis. Jumlah persimpangan didapatkan dengan pengolahan data menggunakan network analysis (Ewing \& Cervero, 2010); (Evans \& Pratt, 2007), dan (Ewing et al., 2006).

\section{Jangkauan Pejalan Kaki}

Jangkauan pejalan kaki atau area tangkapan pejalan kaki (Ped-Sheds) adalah area aktual yang bisa dijangkau dengan berjalan dalam waktu yang ideal ditentukan dari stasiun kereta. Indikator ini dihitung berdasarkan rasio jangkauan pejalan kaki dalam luasan $\mathrm{km}$ persegi dan dibandingkan dengan seluruh area penelitian.

\section{Area Perkantoran}

Pada penelitian ini, indikator pada kriteria area perkantoran mengalami modifikasi. modifikasi tersebut terletak pada dibaginya kantor menjadi tiga jenis yaitu berupa ruko kantor, kantor pemerintah, dan kantor besar.

\section{Kapasitas Stasiun}

Kapasitas stasiun diukur melalui jumlah pengguna commuter line pada setiap stasiun TOD jalur Bogor - Jakarta Kota. Hal ini dilakukan terkait dengan ketersediaan data. Data pengguna atau pengunjung setiap stasiun tahun 2019 pada jalur commuter line Bogor Jakarta Kota tidak seluruhnya tersedia. Oleh karena itu, untuk mendapatkan data jumlah 
pengguna tahun 2019 pada stasiun lainnya, penelitian ini melakukan perhitungan menggunakan rumus prediksi pertumbuhan penduduk, seperti yang ditampilkan pada persamaan (4).

$$
r=\left(\frac{P_{t}}{P_{0}}\right)^{1 / t}-1 \quad P_{t}=P_{0}(1+r)^{t}
$$

Keterangan: $\mathrm{Pt}=$ Jumlah penduduk pada tahun $\mathrm{t} ; \mathrm{P}_{-} 0=$ Jumlah penduduk pada tahun dasar; $\mathrm{r}=$ Laju pertumbuhan penduduk (\%); dan $\mathrm{t}$ = jangka waktu (selisih).

Rumus prediksi pertumbuhan penduduk dipilih berdasarkan asumsi peneliti bahwa setiap tahunnya pengguna commuter line mengalami peningkatan yang berbanding lurus dengan pertumbuhan penduduk. Oleh karena itu, ketika muncul hasil perhitungan jumlah pengguna pada tahun 2019 yang didapatkan dengan menggunakan rumus pertumbuhan penduduk. Peneliti melakukan pencocokan dengan nilai pengguna commuter line pada tahun 2019 yang diperoleh dari berbagai sumber dan menghasilkan hasil angka yang mendekati.

\section{Fasilitas Stasiun}

\section{Keselamatan dan Keamanan Stasiun}

Keselamatan dan keamanan adalah salah satu hal terpenting yang memengaruhi pilihan penggunaan transit. Pada penelitian ini, Peraturan Menteri Perhubungan Nomor 48 tahun 2015 tentang standar pelayanan minimum angkutan orang dengan kereta api (Kementerian Perhubungan, 2015) digunakan sebagai acuan untuk mengukur indikator keselamatan dan keamanan stasiun dengan mempertimbangkan situasi dan kondisi ketika penelitian.

\section{Tampilan Informasi di Stasiun}

Semua stasiun harus menampilkan informasi dengan keberadaan sistem tampilan yang jelas dan mudah dilihat setiap stasiun. Informasi yang ditampilkan berupa jam keberangkatan kereta berikutnya dan menuju ke mana (Abdallah, 2017). Indikator ini diukur dengan melihat ada tidaknya tampilan informasi berupa lokasi keberadaan kereta, jam keberangkatan, nomor kereta, dan informasi angkutan lanjutan.

\section{Aksesibilitas dari dan ke Stasiun}

\section{Perjalanan Commuter Line}

Frekuensi perjalanan stasiun kereta dihitung berdasarkan jumlah kereta yang beroperasi pada hari kerja (Senin-Jumat) di setiap stasiun.

\section{Percabangan Jalur di Stasiun}

Indikator ini mengukur jumlah rute kereta yang dapat di akses di setiap stasiun. Percabangan yang dimaksud adalah pilihan jalur yang keluar dari jalur utama.

\section{Ketersediaan Angkutan Alternatif}

Sistem transit yang baik tidak hanya menawarkan aksesibilitas dari sistem kereta rel, tetapi fleksibilitas pada kawasan transit dalam berpindah dan berganti ke moda transportasi umum lainnya. 


\section{Lokasi yang Ditempuh Berjalan Kaki}

Indikator ini mengukur jumlah bangunan pada wilayah penelitian, sehingga dihasilkan berapa banyak lokasi yang dapat di akses oleh pejalan kaki dari stasiun commuter line. Bangunan yang dimaksud meliputi semua jenis tipe bangunan. Asumsinya, setiap bangunan yang ada dalam buffer 500 meter merupakan bangunan yang dapat di akses bagi pengguna commuter line dengan berjalan kaki.

\section{Ketersediaan Lahan Parkir Analisis Spasial Deskriptif}

Indikator lahan parkir meliputi ketersediaan lahan parkir untuk kendaraan roda empat (mobil) dan kendaraan roda dua (motor) yang disediakan oleh PT. KCI.

\section{Analisis Spasial Deskriptif}

Penelitian ini menggunakan analisis spasial deskriptif. Analisis spasial pada penelitian ini dapat menjelaskan karakteristik wilayah dengan berlandaskan indikator TOD indeks. Terdapat dua variabel yang digunakan dalam penelitian ini yaitu variabel internal dan variabel eksternal. Variabel eksternal yang terdiri dari kriteria kepadatan, keragaman penggunaan lahan, kapasitas stasiun, akses untuk berjalan kaki dan area kantor. Kriteria tersebut digunakan sesuai dengan sudut pandangan peneliti. Dalam penelitian ini, keragaman penggunaan lahan menjadi variabel kunci agar dapat menghasilkan karakteristik ruang dan pemanfaatan ruang dalam wilayah penelitian. Sebagai contohnya, ruang yang $\mathrm{A}$ dan $\mathrm{B}$ didominasi oleh kawasan komersial namun pada ruang $\mathrm{A}$ kawasan komersial tersebut didominasi bangunan berupa mall sedangkan pada kawasan B didominasi oleh ruko atau toko-toko kecil. Dengan demikian, akan sangat berbeda karakter ruang yang satu dengan yang lainnya, sehingga akan memberikan hasil yang berbeda

Variabel internal yang terdiri dari kriteria fasilitas stasiun, akses dari dan ke stasiun, dan ketersediaan lahan parkir pada stasiun dianalisis. Variabel-variabel tersebut di analisis dengan bantuan gambar foto yang diperoleh ketika observasi lapang. Oleh karena itu, tampilan visual mengenai kondisi ruang pada kawasan TOD tiap stasiun pada Commuter Line jalur Bogor - Jakarta Kota dalam analisa deskriptif dapat dijelaskan.

\section{Hasil dan Pembahasan}

Lokasi TOD telah ditetapkan berdasarkan peraturan perundang-undangan. Dalam penelitian ini, penetapan unit penelitian, selain bersumber dari peraturan perundangan, juga didapatkan dari berbagai media berita. Berdasarkan sumber-sumber tersebut didapatkan tujuh lokasi TOD pada jalur commuter line Bogor-Jakarta Kota yaitu Stasiun Depok Baru, Pondok Cina, Tanjung Barat, Cawang, Manggarai, Juanda, dan Jakarta Kota. Pada Perpres No. 55 tahun 2018, secara khusus disebutkan bahwa Stasiun Depok Baru, Cawang, dan Jakarta Kota merupakan TOD dengan tipologi TOD Kota (skala layanan regional), sedangkan Stasiun Tanjung Barat, Juanda, Manggarai, dan Pondok Cina merupakan empat lokasi yang dikembangkan sebagai Kawasan Berpotensi TOD pada tipologi TOD Sub Kota dan TOD Lingkungan.

Nilai TOD Indeks pada TOD Jalur Commuter Line Bogor - Jakarta Kota berada pada rentang $0.36-0.70$ (Tabel 5.10). Nilai indeks TOD tertinggi terdapat pada Stasiun Jakarta Kota yang merupakan TOD Kota dan nilai terendah terdapat pada TOD Stasiun Tanjung Barat yang merupakan TOD lingkungan (Gambar 1).

Pola TOD yang terbentuk adalah pola yang beragam, pada bagian selatan dan utara tinggi dan pada bagian tengah cenderung rendah. Pada bagian tengah stasiunnya tergolong sebagai stasiun dengan TOD lingkungan. Variabel yang paling berpengaruh terbagi menjadi 
dua yaitu variabel internal berupa fasilitas stasiun dan variabel eksternal berupa area kantor dan akses dari dan ke stasiun.

\begin{tabular}{|c|c|c|c|c|c|c|c|}
\hline \multicolumn{2}{|c|}{ Depok Baru } & Pondok Cina & Tanjung Barat & Cawang & Manggarai & Juanda & Jakarta Kota \\
\hline & 0.51 & 0.42 & 0.38 & 0.40 & 0.44 & 0.44 & 0.70 \\
\hline \multicolumn{8}{|l|}{0.8} \\
\hline \multicolumn{8}{|l|}{0.7} \\
\hline \multicolumn{8}{|l|}{0.6} \\
\hline \multicolumn{8}{|l|}{0.5} \\
\hline \multicolumn{8}{|l|}{0.4} \\
\hline \multicolumn{7}{|l|}{0.3} & \\
\hline \multicolumn{8}{|l|}{0.2} \\
\hline \multicolumn{8}{|l|}{0.1} \\
\hline \multicolumn{8}{|l|}{0} \\
\hline & Depok Bar & Pondok Cina & Tanjung Barat & Cawang & Manggarai & Juanda & Jakarta Kota \\
\hline \multicolumn{3}{|c|}{ " Sistem Transit yang ramah pengguna } & - Ketersediaz & lahan parkir & \multicolumn{3}{|c|}{ Kapasitas Stasiun } \\
\hline \multicolumn{3}{|c|}{ Kepadatan } & Area Kanto & & \multirow{2}{*}{\multicolumn{3}{|c|}{ - Keragaman penggunaan lahan }} \\
\hline \multicolumn{3}{|c|}{ Akses untuk berjalan kaki } & Akses dari & ke stasiun & & & \\
\hline
\end{tabular}

\section{Gambar 1. TOD Indeks pada TOD Commuter Line Bogor - Jakarta Kota}

TOD Stasiun Jakarta Kota yang memiliki nilai TOD Indeks paling tinggi, tentunya sangat didukung oleh variabel internal dan variabel eskternal. Pada penelitian ini kedelapan kriteria digolongkan ke dalam dua variabel yaitu variabel internal dan variabel eksternal. Variabel internal terdiri dari fasilitas stasiun dan ketersediaan lahan parkir, sedangkan variabel eksternal terdiri dari kepadatan, keragaman penggunaan lahan, akses dengan jalan kaki, area perkantoran, kapasitas stasiun, dan aksesibilitas dari dan ke stasiun. Aspek keamanan, keselamatan, dan kenyamanan serta adanya parkir sebagai variabel internal pada stasiun Jakarta Kota kondisinya sangat baik. Kondisi lingkungan sebagai variabel eksternal di wilayah analisis pada Stasiun Jakarta Kota menunjukkan bahwa area perkantoran atau bangunan kantor paling banyak ditemui. Sehubungan dengan itu, area komersil juga banyak ditemui. Area komersil terdapat pada wilayah analisis stasiun Jakarta Kota tidak hanya berupa toko atau ruko namun banyak ditemuinya Mall atau Plaza, hal ini tentunya berkaitan dengan kondisi masa lalu Jakarta Kota yang dahulunya sebagai pusat perdagangan dan saat ini fungsi tersebut masih tetap ada. Stasiun Jakara Kota sebagai bagian dari kota tua dikelilingi oleh bangunan-bangunan yang memiliki berbagai fungsi (Cervero \& Dai, 2014). Akses dari dan ke stasiun berupa moda transportasi lanjutan juga mudah ditemui dan tersedia sangat banyak pada bagian depan Stasiun Jakarta Kota sehingga memudahkan para pengguna untuk berganti moda transportasi. Stasiun ini ditetapkan pemerintah sebagai TOD dengan tipologi kota dan memenuhi persyaratan sebagai TOD dengan tipologi kota (Gambar 2). 


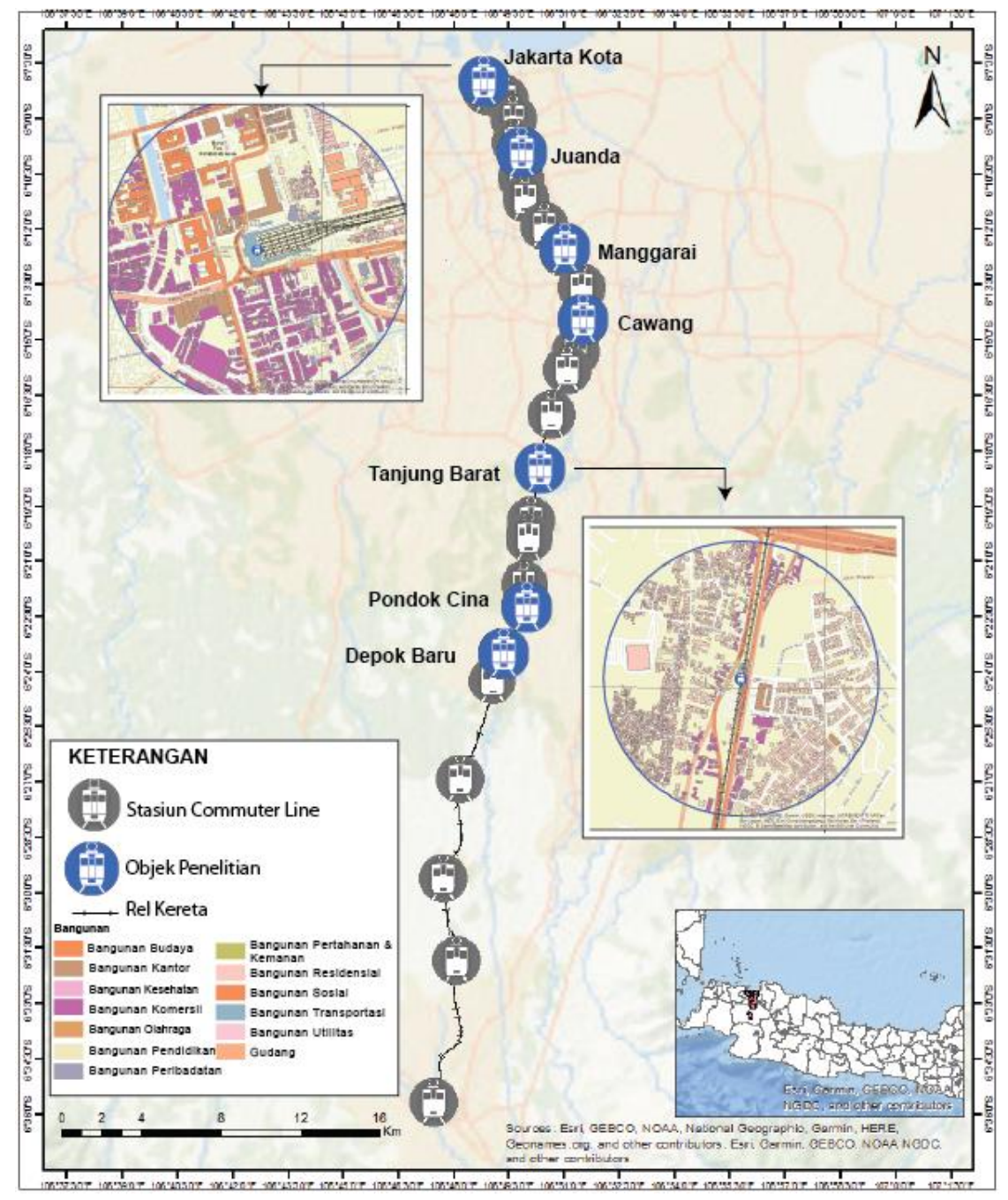

Gambar 2. Objek Penelitian pada Jalur Commuter Line Bogor-Jakarta Kota

Stasiun Depok Baru, yang ditetapkan pemerintah sebagai tipologi TOD Kota memiliki nilai TOD Indeks tertinggi kedua, yaitu dengan nilai 0.51. TOD ini memenuhi seluruh kriteria dari variabel eksternal (Sulistyaningrum \& Sumabrata, 2018). Namun, dikarenakan pemanfaatan ruang pada Depok Baru, terdiri atas $70 \%$ bangunan residensial dan 30\% nonresidensial dan berada pada lingkungan hunian dengan akses baik ke pusat kota atau subpusat kota, secara teori menjadikannya lebih cocok digolongkan sebagai TOD dengan tipologi lingkungan. Stasiun Depok Baru juga memiliki kelemahan yaitu tidak memenuhinya kebutuhan pengguna karena dibandingkan dengan kriteria fasilitas stasiun tidak terpenuhi (Gambar 3). Hal ini tentunya dapat menjadi masukkan bagi PT. KCI untuk meningkatkan indikator keamanan, kenyamanan dan ketersediaan informasi melihat banyaknya jumlah pengguna stasiun.

Nilai TOD indeks rendah yaitu berada pada angka 0,4, dan terdapat pada TOD stasiun Cawang. TOD Stasiun Cawang ditetapkan oleh pemerintah dengan tipologi Kota, namun faktanya tidak memenuhi persyaratan sebagai TOD dengan tipologi kota. Hal ini disebabkan variabel eksternal terdiri atas area perkantoran yang rendah dan variabel internal, tidak tersedianya lahan parkir. Lahan parkir penting untuk disediakan agar pengguna dapat menggunakan lahan parkir tersebut sebagai park and ride dari sebuah 
TOD. Namun, Stasiun Cawang sebetulnya memiliki potensi untuk lebih banyak melayani penumpang karena tingginya kepadatan dan baiknya akses dari dan ke stasiun berupa sistem pada lingkungan 500 meternya.

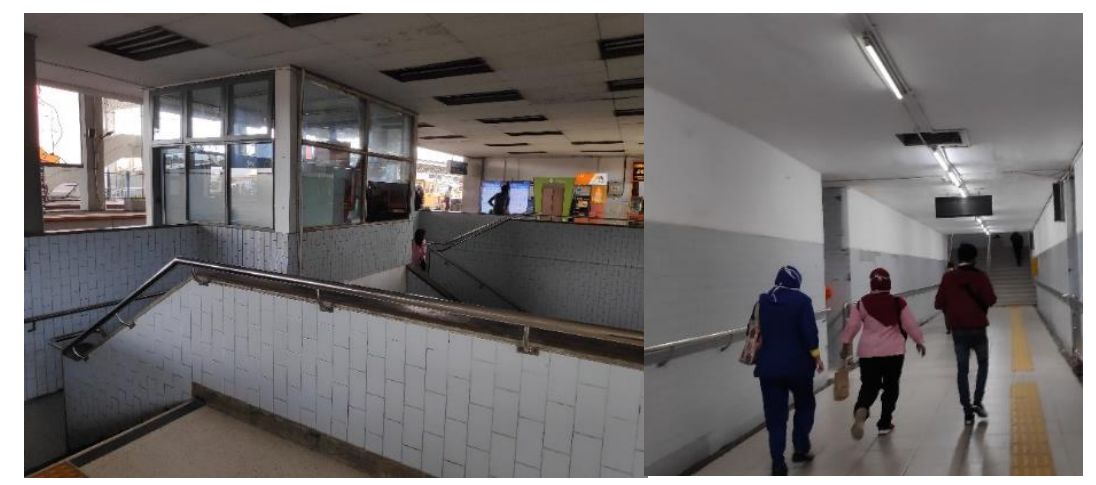

Gambar 3. Minimnya Penerangan, Petugas Keamanan, dan Papan Informasi pada Stasiun Depok Baru

TOD Stasiun Manggarai dan Juanda memiliki nilai indeks yang sama yaitu 0,44 dan keduanya juga ditetapkan pemerintah sebagai Kawasan berpotensi TOD lingkungan. Namun, apabila dilihat dari pemanfaatan ruangnya, pada TOD stasiun Manggarai dan Juanda keduanya memiliki pemanfaatan ruang yang berbeda. Pada TOD stasiun Manggarai pemanfaatan ruang terdiri atas $72 \%$ bangunan residensial dan $28 \%$ non residensial menjadikannya tepat apabila digolongkan sebagai TOD dengan tipologi lingkungan. Sedangkan, pada TOD stasiun Juanda pemanfaatan ruang terdiri atas $17 \%$ bangunan residensial dan $83 \%$ non residensial, sehingga menjadikannya kurang tepat apabila digolongkan sebagai TOD lingkungan jika mengacu pada Perpres No.55 tahun 2018 dan secara teori stasiun ini lebih tepat digolongkan sebagai TOD kota. Meskipun demikian, TOD ini memiliki keunggulan berupa bangunan stasiun yang besar, sistem transportasi yang baik, difungsikan sebagai $h u b$, memiliki lahan parkir sebagai fasilitas park and ride, dan didukung dengan fasilitas stasiun yang baik. Meskipun saat ini lingkungan di sekitar stasiun Manggarai didominasi oleh permukiman namun hal ini dapat ditingkatkan karena pada radius tersebut masih banyaknya lahan yang sebetulnya milik PT. KAI. Stasiun Juanda yang secara teori lebih tepat digolongkan sebagai TOD dengan tipologi kota, membutuhkan peningkatan dalam ketersediaan lahan parkir. Lahan parkir penting untuk disediakan agar pengguna dapat menggunakan lahan parkir tersebut sebagai park and ride dari sebuah TOD.

TOD Stasiun Pondok Cina memiliki nilai 0.42 dan oleh pemerintah ditetapkan sebagai TOD dengan tipologi lingkungan. Namun, faktanya TOD ini secara teori lebih tepat digolongkan sebagai TOD kota hal ini dikarenakan pemanfaatan ruang terdiri atas $18 \%$ bangunan residensial dan $82 \%$ non residensial. Meskipun TOD ini memiliki bentuk bangunan fisik stasiun yang tidak terlalu besar namun nyatanya secara fungsinya cukup baik karena didukung oleh vaiabel internal dan variabel eksternalnya. Dalam penelitian Taki et al. (2017) dinyatakan bahwa TOD di wilayah suburban mengalami pematangan sebagai kota yang mandiri. Hal ini terbukti di stasiun Depok, namun belum terjadi di stasiun Pondok Cina

Nilai TOD index paling rendah ada pada stasiun Tanjung Barat yaitu berada pada angka 0.38, hal ini disebabkan karena variabel eksternal yang membentuk sangat minim area perkantoran dan area komersil. Stasiun ini ditetapkan oleh pemerintah sebagai TOD lingkungan dan secara teoripun sesuai. 


\section{Kesimpulan}

Nilai indeks TOD tertinggi terdapat pada Stasiun Jakarta Kota yang merupakan TOD Kota dan nilai terendah terdapat pada TOD Stasiun Tanjung Barat yang merupakan TOD lingkungan. Pola TOD yang terbentuk adalah pola yang beragam, pada bagian selatan dan utara tinggi dan pada bagian tengah cenderung rendah, sedangkan pada bagian tengah stasiunnya tergolong sebagai stasiun dengan TOD lingkungan. Variabel yang paling berpengaruh terbagi menjadi dua yaitu variabel internal berupa fasilitas stasiun dan variabel eksternal berupa area kantor dan akses dari dan ke stasiun. Penelitian ini menunjukkan bahwa status sebagai TOD lingkungan atau kota tidak selalu memberikan nilai indeks yang tinggi. Sedang pada indeks yang tinggi, tidak selalu kedua variabelnya memberikan peran yang sama.

\section{Daftar Pustaka}

Abdallah, T. (2017). Sustainable mass transit: Challenges and opportunities in urban public transportation. Elsevier Science.

Arif, F. N., \& Manullang, O. R. (2017). Kesesuaian tata guna lahan terhadap penerapan konsep Transit Oriented Development (TOD) di Kota Semarang. Jurnal Pembangunan Wilayah dan Kota, 13(3), 301-311.

Badan Pengelola Transportasi Jabodetabek. (2018). Rencana induk transportasi Jabodetabek (RITJ). Retrieved from: https://bptj.dephub.go.id/rencana-induk-transportasi-jabodetabek-ritj.

Cervero, R., \& Dai, D. (2014). BRT TOD: Leveraging transit oriented development with bus rapid transit investments. Transport Policy, 36, 127-138. doi:10.1016/j.tranpol.2014.08.001.

Cervero, R., Murphy, S., Ferrel , C., Goguts , N., Tsai, Y.-H., Arrington, G. B., McKay, S. (2004). Transit-oriented development in the United States: Experiences, challenges, and prospects. Washington, DC: The National Academies Press. doi:10.17226/23360.

Evans, J. E.; Pratt, R. H. (2007). Transit oriented development transit cooperative research program (TCRP) report 95: Traveler response to transporartion system changes handbook (3 ed.). U.S.A: Transport Research Board of the National Academies.

Ewing, B., van Hal, E., de Jong, M., \& de Jong, T. (2006). Urban design and traffic: A selection from Bach's toolbox (Stedenbouw en verkeer: een selectie uit de gereedschapskist van Bach). Ede: CROW.

Ewing, R., \& Cervero, R. (2010). Travel and the built environment. Journal of the American Planning Association, 76(3), 265-294. doi:10.1080/01944361003766766.

Hasibuan, H. S. (2014). The role of Transit Oriented Development in constructing urban environment sustainability, the case of Jabodetabek, Indonesia. Procedia Environmental Science, 20, 622-631. doi:10.1016/j.proenv.2014.03.075.

Institute of Transportation and Development Policy (ITDP). (2017). TOD standard. Institute of Transportation and Development Policy.

Jacobs, J. (1961). The death and life of great American Cities. New York: Random House.

Kamruzzaman, M., Baker, D., Washington, S., \& Turrell, G. (2014). Advance transit oriented development typology: Case study in Brisbane, Australia. Journal of Transport Geography, 34, 54-70. doi:10.1016/j.jtrangeo.2013.11.002.

Kementerian Perhubungan. (2015). Peraturan Menteri Perhubungan Nomor 48 tahun 2015 tentang standar pelayanan minimum angkutan orang dengan kereta api. Kementerian Perhubungan.

Knupfer, S. M., Pokotilo, V., \& Woetzel, J. (2018). Element of success: Urban transportation system off 24 global cities. McKinsey Center for Future Mobility.

Mungkasa, O. (2018). Transit Oriented Development (TOD) di Provinsi DKI Jakarta: Konsep - perkembangan terkini - agenda kedepan. Seminar Nasional Green Architecture in the Tropic XII 'Transit-Oriented Development: Urban Planning and Design', Jakarta, 24 Oktober 2018.

Newman, P. (2009). Planning for transit oriented development: Strategic principles. In C. Curtis., J. Renne \& L. Bertolin (Ed.), Transit oriented development: Making it happen (pp. 13-22). Burlington VT: Ashgate. 
Nusdwinuringtyas, N. (2018). Six minute walking distance cut-off point in Indonesian (Mongoloid) population. Journal of The Indonesian Medical Association, 68(8).

Pemerintah Republik Indonesia. (2018). Peraturan Presiden Nomor 55 tahun 2018 tentang Rencana Induk Transportasi Jabodetabek tahun 2018 - 2029. Jakarta.

Rahmat, A., Endot, I. R., Ishak, S., Ahmad, Z., Ishak, Z., \& Ibrahim, C. K. I. (2016). Development of Transit Oriented Development (TOD) model for Malaysia. Journal of Built Environment, Technology and Engineering, 1, 36-47.

Sari, F. M. (2019). 5 transportasi umum andalan warga Jakarta. Retrieved from: https://www.liputan6.com/bisnis/read/3958542/5-transportasi-umum-andalan-warga-jakarta.

Siburian, T. E., Sumadio, W., \& Ash Sidiq, I. P. (2020). Characteristics of Transit Oriented Development area (case study: Jakarta MRT). Jurnal Geografi Lingkungan Tropik, 4(1), 46-58.

Singh, Y. J. (2015). Measuring Transit-Oriented Development (TOD) at regional and local scales - a planning support tool. (Doctoral dissertation, University of Twente, Enschede, The Netherlands). Retrieved from https://webapps.itc.utwente.nl/librarywww/papers_2015/phd/singh.pdf.

Singh, Y. J., Lukman, A., Flacke, J., Zuidgeest, M., \& Van Maarseveen, M. F. A. M. (2017). Measuring TOD around transit nodes - Towards TOD policy. Transport Policy, 56, 96-111. doi: 10.1016/j.tranpol.2017.03.013.

Sulistyaningrum, S., \& Sumabrata, J. (2018). Transit Oriented Development (TOD) index at the current transit nodes in Depok City, Indonesia. IOP Conference Series: Earth and Environmental Science, 126. doi: 10.1088/1755-1315/126/1/012217.

Taki, H. M., Maatouk, M. M. H., Qurnfulah, E. M., \& Aljoufie, M. O. (2017). Planning TOD with land use and transport integration: a review. Journal of Geoscience, Engineering, Environment, and Technology, 2(1), 84-94.

Zhang, Y., \& Guindon, B. (2006). Using satellite remote sensing to survey transport-related urban sustainability: Part 1: Methodologies for indicator quantification. International Journal of Applied Earth Observation and Geoinformation, 8(3), 149-164. doi:10.1016/j.jag.2005.08.005. 